\title{
RETENSI DAN INOVASI FONOLOGIS PROTOBAHASA MELAYIK PADA BAHASA MELAYU TAMIANG
}

Phonological Retention and Innovation of Melayik Protolanguage in Tamiang Melayu

\author{
Muhammad Toha \\ Balai Bahasa Provinsi Aceh
}

\begin{abstract}
Abstrak
Penelitian Protobahasa Melayik ini dilakukan secara diakronis. Tujuan dari penelitian ini adalah untuk mendeskripsikan fonem PM yang mengalami retensi dan inovasi pada bahasa Melayu Tamiang (BMT) ditinjau dari persepektif diakronis. Data yang digunakan sebanyak 400 kosakata. Pengumpulan data dilakukan di Kampung Durian, Kec. Rantau, Desa Rantau Bintang, Kec. Bandar Pusaka, Desa Sekerak Kanan, Kec. Sekerak, dan Desa Bandar Khalifah, Kec. Tamiang Hulu. Pengumpulan data dilakukan dengan metode simak dan cakap dengan teknik catat dan rekam. Data dianalisis dengan menerapkan metode kualitatif. Hasil penelitian secara diakronis menunjukkan fonem vokal PM seperti $/ * \mathrm{a} /, / * \partial /, / * \mathrm{i} /$, dan $/ * \mathrm{u} /$ masih diwariskan oleh BMT hingga kini. Namun inovasi terjadi pada vokal $* \mathrm{u}</ \mathrm{U} /$ dan $* \mathrm{a}</ \mathrm{O} /$. Inovasi terjadi dengan sejumlah fonem konsonan PM, seperti $/ * \mathrm{~b} /, / * \mathrm{~d} /, / * \mathrm{~g} /, / * \mathrm{~h} /, / * \mathrm{j} /, / * \mathrm{k} /, / * \mathrm{l} /, / * \mathrm{~m} /, / * \mathrm{n} /, / * \mathrm{p} /, / * \mathrm{r} /$, $/ *_{\mathrm{s}} /, / *_{\mathrm{t}} /, / *_{\mathrm{w}} /, / *_{\mathrm{y} /,} / *_{\mathrm{n}} /, / *_{\mathrm{y}} /$, dan $/ * \mathrm{*} /$ masih dipertahankan oleh BMT sampai saat ini. Fonem konsonan yang mengalami inovasi adalah $* \mathrm{~h}<\varnothing /, * \mathrm{k}</$ ? /, * $1</$ ?/, $* \mathrm{r}</ \mathrm{R} /, * \mathrm{~s}</ \mathrm{h} /$ dan $* \mathrm{t}</$ ?/.

Kata bunni. Malarn Tamiana dialabtolori diakronic ratanci dan innvaci
\end{abstract}

\begin{abstract}
This research was conducted diachronically. The object of this research is the PM phonemes which experienced retention and innovation in Melayu Tamiang language which observed the diachronic perspective. The data used in this research are 400 vocabularies. It was collected in Durian Village, Rantau District; Rantau Bintang Village, Bandar Pusaka District; Sekerak Kanan Village, Sekerak District and Bandar Khalifah Village, Tamiang Hulu District. The data was collected using listening and speaking method along with registering and recording techniques. The data were analysed using qualitative method. Diachronically, the result of the research showed that PM vowels, such as /*al, $/ * \partial /, / *_{i} /$ and $/ *_{u} /$ are still passed down by BMT until now. However, there are innovation occurred to $* u</ U /$ and $* a</ O /$ vowels. Similarly, some PM consonants such as $/ * b /, / * d /, / * g /, / * h /, / * j /, / * k /, / * l /, / * m /, / * n /, / * p /, / * r /, / *_{s} /$, $/ * t /, / *_{w} /, / *_{y} /, / *_{n} /, / *_{y} /$ and $/ * 2 /$ are still maintained by BMT, while the consonant phonemes which experienced innovation are $* h<\emptyset /, * k</ ? /, * l</ ? /, * r<$ $/ R /, * s</ h /$ and $* t</ ?$.
\end{abstract}

Key words: Melayu Tamiang, diachronic dialectology, retention and innovation

\section{PENDAHULUAN}

Menurut Sugono (2008), sebanyak 442 bahasa daerah terdapat di Indonesia. Keberadaannya diatur dalam sebuah Undang-Undang Kebahasaan Nomor 24/2009. Bab 1 Ketentuan Umum pasal 1 ayat 6 menyatakan bahwa bahasa daerah adalah bahasa yang 
digunakan turun temurun oleh warga negara Indonesia di daerah-daerah di wilayah Negara Kesatuan Repubik Indonesia. Bahasa daerah, dalam penjelasan pasal 36, bab XV, UndangUndang Dasar 1945, disebut sebagai salah satu unsur kebudayaan nasional yang perlu dipelihara dan dikembangkan. Menurut Mahsun (1999) upaya memelihara bahasa daerah perlu dilakukan karena sikap penutur bahasa daerah yang kurang positif terhadap bahasa daerahnya. Hal ini disebabkan penutur bahasa daerah (sebagian besar bahasa daerah yang ada di Indonesia) yang relatif kecil jumlahnya. Oleh karena itu, mereka memandang dirinya sebagai kelompok minoritas yang kurang prestise dan pemakaian bahasa Indonesia yang semakin dominan dalam berbagai aspek kehidupan. Upaya pengembangan dilakukan melalui penelitian bahasa-bahasa daerah, seperti pada aspek kebahasaannya.

Salah satu bahasa daerah itu adalah Bahasa Melayu yang tersebar di hampir seluruh Indonesia. Sebaran bahasa Melayu juga sampai ke Provinsi Aceh. Di provinsi ini bahasa Melayu disebut bahasa Tamiang. Sejumlah pendapat mengatakan jika bahasa Tamiang merupakan bahasa Melayu, khususnya Melayu Deli (lihat Akbar, dkk., 1985, Durie, 1985:1) serta Dado Meuraxa (1956) dan Rusdi Sufi, et al., (2004). Mungkin atas dasar itulah Lumban Batu (1998) menggunakan istilah bahasa Melayu Tamiang dalam penelitiannya di Kabupaten Aceh Tamiang. Berdasarkan paparan di atas, bahasa Tamiang dalam artikel ini selanjutnya disebut bahasa Melayu Tamiang (BMT). Penelitian lainnya dilakukan Balai Bahasa Provinsi Aceh (2007) yang mengelompokkan BMT sebagai bahasa sendiri yang berbeda dengan bahasa-bahasa daerah lainnya.

Dalam kehidupan sehari-hari, di wilayah tuturnya di Kabupaten Aceh Tamiang, BMT digunakan sebagai alat komunikasi di dalam keluarga maupun di masyarakat. Selain itu, BMT sebagai lambang kebanggaan dan identitas daerah tersendiri bagi etnis Tamiang. Demikian pula halnya dalam kebudayaan seperti pada acara perkawinan. BMT digunakan dalam pantun ketika menyambut calon mempelai pria di rumah calon mempelai wanita. Sayangnya, saat ini tradisi berpantun dalam adat perkawinan etnis Tamiang terbatas pada daerah tertentu saja.

Seperti yang dijelaskan bahwa kajian yang pernah dilakukan terhadap BMT pada aspek kebahasaannya belum banyak dilakukan. Diantaranya yang dilakukan Lumban Batu (1998) yang meneliti pada aspek sintaksis. Balai Bahasa Provinsi Aceh (2007) mengkaji perbedaan pada unsur-unsur bunyi yang terdapat di dalam BMT. Penelitian itu dilakukan secara sinkronis, tanpa melibatkan perkembangan historis. Dengan demikian, diduga penelitian linguistik secara diakronis terhadap BMT belum pernah dilakukan.

Linguistik diakronis adalah subdisiplin lingusitik yang menyelidiki perkembangan suatu bahasa dari masa ke masa. Studi diakronis bersifat vertikal, misalnya menyelidiki 
perkembangan bahasa Indonesia yang dimulai sejak zaman adanya prasasti di Kedukan Bukit sampai kini. Penelitian linguistik secara diakronis dalam kajian ini menggunakan pendekatan top-down approach untuk menentukan unsur fonologi yang mengalamai inovasi. Dalam hal ini top-down approach dilakukan antara bahasa induk dengan BMT yang pernah menjalin kontak dengan penutur bahasa tersebut. Untuk itu, bahasa induk yang digunakan adalah penelitian Melayik Purba atau Protobahasa Melayik (PM) Adelaar (1992). Dalam penelitian ini, kajian secara diakronis dimaksudkan pada upaya membuat analisis inovatif dan retensif.

Menurut Mahsun, (1995:83) dalam ilmu linguistik unsur-unsur kebahasaan yang mengalami perubahan dalam bahasa, dialek/subdialek yang diteliti itu disebut inovasi. Kemudian, Mahsun (1995:84) menjelaskan dalam kajian dialektologi inovasi mengandung pengertian bahwa unsur-unsur yang berupa inovasi itu merupakan unsur yang sama sekali baru, Jadi, bukan unsur pewarisan dari suatu bahasa purba yang telah mengalami adaptasi sesuai dengan kaidah perubahan bunyi yang berlaku. Djantra Kawi dalam Mahsun (1995:84) mencontohkan kata [iwak] 'ikan' pada dialek Banjar. Kata tersebut merupakan inovasi (pengaruh bahasa Jawa) karena distribusi kata itu terbatas pada dialek Banjar saja, tidak terdapat pada bahasa Melayu lain (dialek Banjar termasuk rumpun bahasa Melayu). Bahasabahasa Melayu lainnya menggunakan kata [ikan] untuk merealisasikan makna tersebut.

Selain dapat berubah, unsur-unsur kebahasaan dapat pula statis atau tidak berubah atau bertahan yang disebut retensi. Artinya pada bahasa, dialek/subdialek tertentu masih dapat ditemukan warisan unsur-unsur kebahasaan lama yang merupakan warisan dari bahasa purba yang menurunkan bahasa, dialek/subdialek tersebut.

Dengan demikian masalah yang dibicakarakan dalam penelitian ini adalah bagaimanakah retensi dan inovasi yang terjadi dalam fonem BMT? Oleh sebab itu, tujuan yang hendak dicapai melalui penelitian ini adalah untuk mendeskripsikan bentuk retensi dan inovasi fonem dari bahasa Protonya pada BMT.

\section{LANDASAN TEORI}

Penelitian ini dilatarbelakangi adanya sejumlah penelitian dan tulisan tentang bahasabahasa di Aceh. Diantaranya dilakukan:

Lumban Batu (1998) mengkaji Sintaksis kalimatnya BMT. Penelitian ini difokuskan pada ciri-ciri dan jenis-jenis kalimat BMT yang terdapat di Kecamatan Karang Baru. Cakupan daerah dalam penelitian ini dalam satu Kabupaten Aceh Tamiang dilakukan pada satu kecamatan saja. Akbar dkk, (1985) menulis Pemetaan Bahasa Aceh, Alas, dan Gayo. Penelitian ini menggunakan 350 kosakata yang terdiri dari 200 kosakata bahasa Indonesia 
yang sebagian termasuk dalam daftar kata Swadesh, 100 kata serapan dari bahasa Arab, dan masing-masing 25 kata serapan dari bahasa Belanda dan bahasa asing lainnya. Data yang dihimpun berasal dari 18 daerah kecamatan pada kantung masing-masing ketiga bahasa di atas. Perbandingan dilakukan antardialek masing-masing bahasa atau tidak sampai pada level antarbahasa. Penelitian Voorhoeve, yang berjudul Critical Survey of Studies on the Languages of Sumatra (dalam Akbar, 1980:2) menyatakan adanya 4 bahasa di provinsi Aceh yakni bahasa Aceh, Gayo, Simalur, dan Sikhule. Penelitian ini tidak menjelaskan jumlah data yang dianalisis dan metode yang digunakan di dalamnya. Hasan, dkk. dalam Kesenian Gayo dan Perkembanganya, menyebut adanya BMT sebagai salah satu bahasa daerah yang terdapat di Provinsi Aceh. Penelitian tersebut memetakan daerah kediaman asli suku-suku bangsa di Aceh berdasarkan sumber Lembaga Sejarah dan Purbakala Departemen P \& K (dalam Akbar, 1980:2-3). Tim Pemetaan Bahasa Balai Bahasa Provinsi Aceh, (2007) dalam Hubungan Kekerabatan dan Pemetaan Bahasa-Bahasa di Provinsi Nanggore Aceh Darussalam mengkaji keberadaan bahasa-bahasa di Provinsi Aceh. Penelitian ini menggunakan 400 kosakata. Hasil dari penghitungan dialektometri menyatakan adanya 8 bahasa di Provinsi Aceh, yaitu, bahasa Aceh, Devayan, Sigulai, Gayo, Jawa, Minang, Batak, dan Melayu. Langkah

\section{METODE PENELITIAN}

Penelitian ini menggunakan metode deksriptif kualitatif, yaitu mendeskripsikan inovasi dan retensi fonem vokal dan konsonan pada BMT. Kekualitatifan penelitian ini berkaitan dengan data yang dianalisis berupa fonem.

Sumber data berasal dari Kabupaten Aceh Tamiang Provinsi Aceh pada empat daerah pengamatan, yakni Desa Kampung Durian, Kec. Rantau; Desa Rantau Bintang, Kec. Bandar Pusaka; Desa Sekerak Kanan, Kec. Sekerak; Desa Bandar Khalifah, Kec. Tamiang Hulu. Sumber data diperoleh melalui kegiatan pengumpulan data dari informan yang menetap di daerah pengamatan. Instrumen yang digunakan dalam penelitian ini berupa daftar tanyaan yang memuat 400 kosakata; 200 kosakata Swadesh (Revisi Blust, 1980) dan 200 kosakata Budaya Dasar yang meliputi Bagian Tubuh (52 kosakata), Sistem Kekerabatan (25 kosakata), Gerak Tubuh ( 98 kosakata), dan Kata Tugas (25 kosakata).

Penetapan jumlah 400 kosakata sebagai data karena dua alasan. Pertama, mengacu pada jumlah dan tipe data yang sama yang digunakan oleh Badan Pengembangan dan Pembinaan Bahasa, Kementerian Pendidikan Nasional atau Badan Bahasa dalam penelitian Hubungan Kekerabatan dan Pemetaan Bahasa-Bahasa Daerah di Indonesia yang berlangsung 
sejak tahun 1992. Kedua, kosakata ini sudah teruji sebagai kosakata yang selalu memiliki berian pada semua isolek yang diteliti. (Riswara, 2011:33).

Pengumpulan data dilakukan dengan metode simak dan metode cakap, Sudaryanto, (1988b:2). Metode simak diterapkan pengumpul data dengan menyimak penggunaan bahasa lisan yang dituturkan informan selama proses wawacara. Adapun metode cakap ditempuh dengan cara bercakap-cakap antara pengumpul data dengan informan. Dengan kata lain, terjadi kontak antara pengumpul data dan informan. Kontak ini terjadi di setiap daerah pengamatan. Adapun alat yang digunakan untuk pengumpulan data adalah alat perekam, laptop dan daftar tanyaan.

Analisis data dilakukan dengan menggunakan metode komparatif yang bersifat kualitatif. Langkah penggunaan metode ini adalah dengan merekonstruksi hubungan antarbahasa dengan cara merunutnya berdasarkan anasir warisan fonem dari peringkat yang lebih tinggi (PM) ke tingkat yang lebih rendah (BMT). Ini dilakukan untuk menentukan unsur-unsur yang mengalami inovasi dalam bahasa Melayu Tamiang yang digunakan pada saat sekarang. Adapun protobahasa yang digunakan dari hasil rekonstruksi bahasa Melayik Purba atau Protobahasa Melayik (PM) (Adelaar, 1992).

\section{PEMBAHASAN}

\section{Retensi Vokal}

Fonem vokal yang mengalami retensi atau warisan yang masih dipertahankan BMT dari PM hingga kini ada 4 vokal, yaitu: /*a/, /*2/, /*i/, dan $/ * \mathrm{u} /$.

Bukti adanya retensi vokal PM tersebut pada BMT dari dapat dilihat pada contoh berikut ini:

1) $* a>a / \#-$

Misalnya:

2) $* a>a / K-K$

$\begin{array}{lll}\quad \text { PM } & \text { BMT } & \text { Gloss } \\ \text { *akaR } & \text { akOR } & \text { 'akar' } \\ \text { *anak } & \text { ana? } & \text { 'anak' } \\ \text { *asap } & \text { asap } & \text { 'asap' } \\ \text { *aykat } & \text { ayke' } & \text { 'angkat (me)' }\end{array}$

Misalnya:

\begin{tabular}{lll}
\multicolumn{1}{c}{ PM } & BMT & Gloss \\
*hayam & ayam & 'ayam' \\
*baisan & bisan & 'besan' \\
*qatep & atap & 'atap' \\
*ihekan & ikan & 'ikan' \\
*jalan & jalan & 'jalan'
\end{tabular}

Ranah Volume 5 Nomor 1 Juni 2016|91 
3) $* \partial>1 / \mathrm{K}-\mathrm{K}$

Misalnya:

\begin{tabular}{|c|c|c|}
\hline PM & BMT & Gloss \\
\hline$*_{\mathrm{t} \partial \mathrm{bel}}$ & təbal & 'tebal' \\
\hline *bəli & bəli & 'beli' \\
\hline$*_{p} \partial$ rut & pəRu? & 'perut' \\
\hline$* \mathrm{~d} \partial \mathrm{y} \partial \mathrm{r}$ & dəyOR & \\
\hline *borat & bəR $\varepsilon^{?}$ & 'berat' \\
\hline
\end{tabular}

4) $*_{\mathrm{i}}>\mathrm{i} / \mathrm{\# -}$

Misalnya:

\begin{tabular}{|c|c|c|}
\hline $\mathbf{P M}$ & BMT & Gloss \\
\hline *ikan & ikan & 'ikan' \\
\hline *qitem & itam & 'hitam ' \\
\hline$*^{*}$ hi(y)s $\partial p$ & (y) isap & 'hisap' \\
\hline *ikur & $\mathrm{ikOR}$ & 'ekor' \\
\hline$* \mathrm{ik} \partial \mathrm{t}$ & $\mathrm{ik} \varepsilon^{?}$ & 'ikat' \\
\hline
\end{tabular}

5) $*_{\mathrm{i}}>\mathrm{i} / \mathrm{K}-\mathrm{K}$

Misalnya:

$\begin{array}{lll}\text { PM } & \text { BMT } & \text { Gloss } \\ \text { *anin } & \text { anin } & \text { 'angin' } \\ \text { *inum } & \text { minUm } & \text { 'minum' } \\ \text { *kilat } & \text { kile? } & \text { 'kilat' } \\ \text { *dilah } & \text { lidah } & \text { 'lidah' }\end{array}$

6) $*_{\mathrm{i}}>\mathrm{i} / \mathrm{-}$ \#

Misalnya:

\begin{tabular}{lll}
\multicolumn{1}{c}{ PM } & BMT & Gloss \\
*hari & aRi & 'hari' \\
*kaki & kaki & 'kaki' \\
*gigi & gigi & ',gigi' \\
*tali & tali & 'tali \\
*buni & (bə) buni & 'sembunyi'
\end{tabular}

7) $* u>u / \#-$

Misalnya:

8) $* u>u /-\#$

\begin{tabular}{|c|c|c|}
\hline $\mathbf{P M}$ & BMT & Gloss \\
\hline *ulor & ulOR & 'ular' \\
\hline *uran & uRan & 'orang' \\
\hline *uap & kuwap & 'menguap' \\
\hline$* \mathrm{ut} \partial \mathrm{k}$ & uta? & 'otak' \\
\hline *urat & $\mathrm{uR} \varepsilon^{?}$ & 'urat' \\
\hline
\end{tabular}

Misalnya:

$\begin{array}{lll}\text { PM } & \text { BMT } & \text { Gloss } \\ \text { *tahu } & \text { tau } & \text { 'tahu' } \\ \text { *malu } & \text { malu } & \text { 'malu' } \\ \text { *baharu } & \text { baRu } & \text { 'baru' } \\ \text { *batu } & \text { batu } & \text { 'batu' } \\ \text { *habu } & \text { abu } & \text { 'abu' }\end{array}$




\section{Retensi Konsonan}

Fonem konsonan yang mengalami retensi atau warisan, yang masih dipertahankan BMT dari PM sampai kini sebanyak 16 konsonan, yaitu: /*p/, /*d/, /*b/, /*g/, /*h/, /*j/, /*k/, $/ * 1 /, / * \mathrm{~m} /, / * \mathrm{n} /, / * \mathrm{~s} /, / * \mathrm{t} /, / * \mathrm{w} /, / * \mathrm{y} /, / * \sim \mathrm{n} /$, dan $/ * \mathrm{G} /$.

Bukti adanya retensi konsonan PM tersebut pada BMT dari dapat dilihat pada contoh berikut ini:

1) $* p>p / \#-$

Misalnya:

2) $* p>p / K-K$

$\begin{array}{cl}\text { No } & \text { PM } \\ \text { 1. } & \text { *porut } \\ \text { 2. } & \text { *putih } \\ \text { 3. } & \text { *pandak } \\ \text { 4. } & \text { *pusat } \\ \text { 5. } & \text { *porəs }\end{array}$

$\begin{array}{ll}\text { BMT } & \text { Glos } \\ \text { pəRu' } & \text { 'perut' } \\ \text { putlh } & \text { 'putih' } \\ \text { pend } \varepsilon^{?} & \text { 'pendek' } \\ \text { puse } & \text { 'pusat' } \\ \text { pəRah } & \text { 'memeras' }\end{array}$

Misalnya:

3) $* p>p /-\#$

$\begin{array}{cl}\text { No } & \text { PM } \\ \text { 1. } & \text { *ompat } \\ \text { 2. } & \text { *rumput } \\ \text { 3. } & \text { *impi }\end{array}$

$\begin{array}{ll}\text { BMT } & \text { Glos } \\ \text { əmpa' } & \text { 'empat' } \\ \text { RumpU' } & \text { 'rumput' } \\ \text { mimpi } & \text { 'bermimpi' }\end{array}$

Misalnya:

4) $* d>d / \#$ -

$\begin{array}{cl}\text { No } & \text { PM } \\ \text { 1. } & \text { *asap } \\ \text { 2. } & \text { *hatop } \\ \text { 3. } & \text { *sayap } \\ \text { 4. } & \text { *hidup } \\ \text { 5. } & \text { *uap }\end{array}$

BMT

asap

atap

sayap

idUp

kuwap
Glos
'asap'
'atap'
'sayap'
'hidup'
'menguap'

Misalnya:

5) $* d>d / K-K$

$\begin{array}{cl}\text { No } & \text { PM } \\ \text { 1. } & * \text { dada } \\ \text { 2. } & * \text { duduk } \\ \text { 3. } & * \text { dari } \\ \text { 4. } & \text { *dagin } \\ \text { 5. } & \text { *darah }\end{array}$

$\begin{array}{ll}\text { BMT } & \text { Glos } \\ \text { dadO } & \text { 'dada' } \\ \text { dudU' } & \text { 'duduk' } \\ \text { daRi } & \text { 'dari' } \\ \text { dagin } & \text { 'daging' } \\ \text { daRah } & \text { 'darah' }\end{array}$

Misalnya:
No PM
1. *hidung
2. *hidup
3. *mandi
4. *tidur
5. *ludah

BMT

idUn

idUp

mandi

tidUR

(yə) ludah
Glos

'hidung'

'hidup'

'mandi'

'tidur'

'meludah' 
6) $* b>b / \#$ -

Misalnya:

\section{No PM}

1. *buka

2. *bintan

3. *buna?

4. *bulan

5. *borat

7) $* b>b / K-K$

Misalnya:

8) $* g>g / \#$ -

Misalnya:

9) $* g$ $>$ g / K - K
No PM

1. *gigi

2. *garuk

\section{BMT}

bukO

bintay

bunO

bulan

$\mathrm{bəR} \varepsilon^{\text {? }}$

\section{Glos}

'buka'

'bintang'

'bunga'

'bulan'

'berat'

Misalnya:

BMT

gigi

gaRu
BMT

RambUy?

temba?

tumbUh

təRbay

kabu?

\section{Glos}

'rambut'

'menembak'

'bertumbuh'

'terbang'

'kabut'

10) $* \mathrm{~h}>\mathrm{h} / \mathrm{K}-\mathrm{K}$

\section{No PM}

1. *dagin

Misalnya:

11) $* \mathrm{~h}>\mathrm{h} / \mathrm{-} \#$
No PM
1. *paha
2. *tahu
3. *lihər
4. *jahit

Misalnya:

12) $* \mathrm{j}>\mathrm{j} / \#-$
No PM
1. *darah
2. *rumah
3. *bunuh
4. *bolah
5. *pilih

Misalnya:

BMT

dagin

BMT
pəhO
tau
leheOR
jal?

Glos

'paha'

'tahu'

'leher'

'menjahit'

\section{Glos}

'daging'

$\begin{array}{ll}\text { BMT } & \text { Glos } \\ \text { daRah } & \text { 'darah' } \\ \text { Rumah } & \text { 'rumah' } \\ \text { bunUh } & \text { 'membunuh' } \\ \text { bəlah } & \text { 'membelah' } \\ \text { pilih } & \text { 'memilih' }\end{array}$

BMT

jalan

jहh $\varepsilon^{\text {? }}$

$\mathrm{jaI}^{\text {? }}$
Glos

'jalan' 'jahat' 'menjahit' 
13) $*_{\mathrm{j}}>\mathrm{j} / \mathrm{K}-\mathrm{K}$
4. *jarum
jaRum
'jarum'
5. *jauh
jauh
'jauh'

Misalnya:

$\begin{array}{cl}\text { No } & \text { PM } \\ \text { 1. } & \text { *tajam } \\ \text { 2. } & \text { *panjan } \\ \text { 3. } & \text { *hujan } \\ \text { 4. } & \text { *hijau }\end{array}$

BMT

tajam

panjay

ujan

ijO

\section{Glos}

'tajam'

'panjang'

'hujan'

'hijau'

14) $* \mathrm{k}>\mathrm{k} / \mathrm{\#}$ -

Misalnya:

15) $* \mathrm{k}>\mathrm{k} / \mathrm{K}-\mathrm{K}$
No PM
1. *kecil
2. *kulit
3. *kanan
4. *kutu
5. *kayu

BMT

kəci?

kuli?

kanan

kutu

kayu

\section{Glos}

'kecil'

'kulit'

'kanan'

'kutu'

'kayu'

Misalnya:

$\begin{array}{cl}\text { No } & \text { PM } \\ \text { 1. } & \text { *buka } \\ \text { 2. } & \text { *ihekan } \\ \text { 3. } & \text { *kaki } \\ \text { 4. } & \text { *akaR } \\ \text { 5. } & \text { *aykat }\end{array}$

BMT

Glos

bukO

ikan

'membuka'

kaki

'ikan'

akOR

'kaki'

ayk $\varepsilon^{\text {? }}$

'akar'

16) $* 1>1 / \#$ -

Misalnya:

$\begin{array}{cl}\text { No } & \text { PM } \\ \text { 1. } & \text { *lihər } \\ \text { 2. } & \text { *ludah } \\ \text { 3. } & \text { *laut }\end{array}$

BMT

Glos

leheOR

'leher'

(yə) ludah

laə?

'meludah'

'laut'

17) $* 1>1 / \mathrm{K}-\mathrm{K}$

Misalnya:

18) $* m>m / \#-$

$\begin{array}{clll}\text { No } & \text { PM } & \text { BMT } & \text { Glos } \\ \text { 1. } & \text { *kulit } & \text { kuli' } & \text { 'kulit' } \\ \text { 2. } & \text { *tulay } & \text { tulay } & \text { 'tulang' } \\ \text { 3. } & \text { *mulut } & \text { mulU' } & \text { 'mulut' }\end{array}$

Misalnya:
No PM
1. *makan
2. *malam
3. *mata
4. *mandi
5. *mulut

$\begin{array}{ll}\text { BMT } & \text { Glos } \\ \text { makan } & \text { 'makan' } \\ \text { malam } & \text { 'malam' } \\ \text { matO } & \text { 'mata' } \\ \text { mandi } & \text { 'mandi' } \\ \text { mulU? } & \text { 'mulut' }\end{array}$


19) $* m>m / K-K$

Misalnya:

20) $* \mathrm{~m}>\mathrm{m} / \mathrm{-}$ \#

No PM

1. *kami

2. *rumah

3. *səmpit

Misalnya:

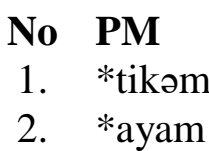

21) $* n>n / \#-$

Misalnya:

22) $*_{n}>n / K-K$

No PM

1. *naik

Misalnya:

23) $* \mathrm{n}>\mathrm{n} / \mathrm{-} \#$

Misalnya:

24) $*_{\mathrm{s}}>\mathrm{s} / \mathrm{H}$ -

Misalnya:

25) ${ }^{\mathrm{s}}>\mathrm{s} / \mathrm{K}-\mathrm{K}$

\section{No PM \\ 1. *bunuh \\ 2. *anak}

$\begin{array}{cl}\text { No } & \text { PM } \\ \text { 1. } & \text { *tahun } \\ \text { 2. } & \text { *tanan } \\ \text { 3. } & \text { *turun } \\ \text { 4. } & \text { *makan } \\ \text { 5. } & \text { *ihekan }\end{array}$

No PM

1. *sayap

2. *sompit

3. *sakit
BMT Glos

kami 'kami'

Rumah 'rumah'

səmpI? 'sempit'
BMT Glos

tikam 'menikam'

ayam 'ayam'
BMT Glos

na $\varepsilon^{\text {? }}$ 'naik'

\section{BMT Glos}

bunUh 'membunuh'

ana? 'anak'

Misalnya:

26) $* \mathrm{t}>\mathrm{t} / \#-$

$$
\begin{array}{cl}
\text { No } & \text { PM } \\
\text { 1. } & \text { *asap } \\
\text { 2. } & \text { *basah } \\
\text { 3. } & \text { *bəsar } \\
\text { 4. } & \text { *busuk }
\end{array}
$$

Misalnya:
No PM
1. *tulis
2. *turun
3. *tanan

\section{BMT}

tulih

tuRun

tanan

\section{BMT Glos}

sayap 'sayap'

səmpi? 'sempit'

saki? 'sakit'

$\begin{array}{ll}\text { BMT } & \text { Glos } \\ \text { asap } & \text { 'asap' } \\ \text { basah } & \text { 'basah' } \\ \text { bəsOR } & \text { 'besar' } \\ \text { busu' } & \text { 'busuk' }\end{array}$

Ranah Volume 5 Nomor 1 Juni 2016|96 
27) $* t>t / K-K$
4. *takut
takU?
'takut'
5. *tidur
tidUR
'tidur'

Misalnya:
No PM
1. *batu
2. *kutu
3. *kita?
4. *datə力
5. *bintay

28) ${ }^{*} \mathrm{~W}>\mathrm{w} / \mathrm{K}-\mathrm{K}$

Misalnya:

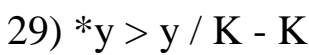

\section{No PM}

1. *awan
BMT

batu

kutu

kitO

datan

bintay

\section{Glos}

'batu'

'kutu'

'kita'

'datang'

'bintang'

Misalnya:

$$
\begin{array}{cl}
\text { No } & \text { PM } \\
\text { 1. } & \text { *ayap } \\
\text { 2. } & \text { *ayam } \\
\text { 3. } & \text { *kayu? }
\end{array}
$$

30) $* \sim \tilde{n}>\sim \tilde{n} / \#-$

Misalnya:

$$
\begin{array}{cl}
\text { No } & \text { PM } \\
1 . & * \tilde{n} a m u k
\end{array}
$$

Dialek Hulu

ñamO?

$\begin{array}{ll}\text { BMT } & \text { Glos } \\ \text { awan } & \text { 'awan' }\end{array}$

BMT

sayap

ayam

kayu
Glos

'sayap'

'ayam'

'kayu'

31) $* \sim \tilde{n}>\sim \tilde{n} / K-K$

Misalnya:

32) $* y>$ y / K - K

No PM

1. *kuñah

\section{BMT}

ku ñah

\section{Glos}

'mengunyah'

Misalnya:

33) $* y>$ y / - \#
No PM
1. *də๊ər
2. *bəykak
3. *buna
4. *tanan
5. *lanit

Misalnya:
No PM
1. *datəy
2. *tulan
3. *hiduy
4. *uray
5. * cacin

Dialek Hulu

dəクOR

bəyka?

buyO

tanan

lani?
Glos

'nyamuk'

\section{Glos \\ 'mendengar' \\ 'bengkak' \\ 'bunga' \\ 'tangan' \\ 'langit'}




\section{Inovasi Vokal}

Fonem vokal yang mengalami inovasi BMT dari PM sebanyak 2, yaitu: /*a/ dan /*u/. Bukti adanya retensi vokal BMT dari PM dapat dilihat pada contoh berikut ini:

refleks PM /*u/ < DTHu /U/ (/K-K) dan refleks PM /*a/ < DTHu /O/ (/- \#)

1. $*^{\mathrm{u}}<\mathrm{U} / \mathrm{K}-\mathrm{K}$

Misalnya:

$\begin{array}{lll}\text { PM } & \text { DTHu } & \text { Gloss } \\ \text { *takut } & \text { takU? } & \text { 'takut' } \\ \text { *mulut } & \text { mulU? } & \text { mulut' } \\ \text { *labuh } & \text { ləbU? } & \text { 'jatuh' } \\ \text { *hidung } & \text { idUG } & \text { 'hidung' }\end{array}$

2. $* \mathrm{a}<0 /-\#$

Misalnya:

$\begin{array}{lll}\text { PM } & \text { DTHu } & \text { Gloss } \\ \text { *mata } & \text { matO } & \text { 'mata } \\ \text { *dia } & \text { diyO } & \text { 'dia' } \\ \text { *dua } & \text { duwO } & \text { 'dua' } \\ \text { *tAlina } & \text { təlinO } & \text { 'telinga' } \\ \text { *buka } & \text { bukO } & \text { 'buka' }\end{array}$

\section{Inovasi Konsonan}

Fonem konsonan yang mengalami inovasi BMT dari PM sebanyak 6, yaitu: /*h/, /* k/, /* 1/, /* r/, /* s/, dan /* t/. Bukti adanya retensi vokal BMT dari PM dapat dilihat pada contoh berikut ini:

refleks PM /*h/ < BMT /Ø/ (/ \# -), refleks PM /* k/ < BMT /?/ (/- \#), refleks PM /*1/< BMT / ?/ (/- \#), refleks PM /* r/ < BMT /R/ (/\# -), refleks PM /* r/ < BMT /R/ (/K-K), refleks PM /* $\mathrm{r} /<\mathrm{BMT} / \mathrm{R} /(/-\#)$, refleks PM /* s/ $<$ BMT /h/ (/- \#) dan refleks PM /* t/ < BMT / ?/ (/- \#).

1) $* \mathrm{~h}>\varnothing / \#-$

Misalnya:

2) $* \mathrm{k}>$ ? / - \#

No PM

1. *hidung

2. *hidup

3. *hati

4. *habu

5. *hi(y)səp

Misalnya:
No PM
1. *pendek
2. *anak

BMT

idUn

idUp

ati

abu

(y) isap

\section{Glos}

'hidung'

'hidup'

'hati'

'abu'

'mengisap'
BMT

pend $\varepsilon^{\text {? }}$

ana?

\section{Glos} 'pendek' 'anak' 
3) $* 1>$ ? / - \#

Misalnya:

4) *r $>$ R / \# -

Misalnya:

5) $* \mathrm{r}>\mathrm{R} / \mathrm{K}-\mathrm{K}$

\section{No PM}

1. *kecil bəyka?

belO? 'bengkak'

'belok'

Misalnya:

\section{No PM \\ 1. *rumput \\ 2. *rumah \\ 3. *rambut \\ 4. * rusuk}

BMT

kəci?

\section{Glos}

'kecil'

\section{BMT Glos}

RumpU? 'rumput'

Rumah 'rumah'

RambUy? 'rambut'

Rusu? 'rusuk'

6) $* r>R /-\#$

Misalnya:

7) $*_{s}>\mathrm{h} / \mathrm{-} \mathrm{\#}$

\section{No PM \\ 1. *dəyər \\ 2. *akaR \\ 3. *ikur \\ 4. *tolur \\ 5. *ulər}

Misalnya:

8) $* \mathrm{t}>$ ? / - \#

Misalnya:
No PM
1. *tulis
2. *atas
3. *tikus
4. *nipis
5. *poras

BMT Glos

pəRu? 'perut'

aRi 'hari'

baRu 'baru'

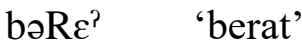

pəRah 'memeras'

$\begin{array}{ll}\text { BMT } & \text { Glos } \\ \text { dəyOR } & \text { 'dengar' } \\ \text { akOR } & \text { 'akar' } \\ \text { ikOR } & \text { 'ekor' } \\ \text { təlUR } & \text { 'telur' } \\ \text { ulOR } & \text { 'ular' }\end{array}$

DBT Glos

tulih 'tulis'

atch 'atas'

tikUh 'tikus'

tipih 'tipis'

pəRah 'memeras'

$\begin{array}{clll}\text { No } & \text { PM } & \text { BMT } & \text { Glos } \\ \text { 1. } & \text { *kulit } & \text { kuli? } & \text { 'kulit' } \\ \text { 2. } & \text { *sakit } & \text { saki? } & \text { 'sakit' } \\ \text { 3. } & \text { *angkat } & \text { anke? } & \text { 'angkat' } \\ \text { 4. } & \text { *borat } & \text { bəRe' } & \text { 'berat' }\end{array}$




\section{SIMPULAN}

Berdasarkan hasil analisis di atas, dapat disimpulkan bahwa bahasa Melayu Tamiang memiliki 17 konsonan yaitu /*b/,/*d $/, / * \mathrm{~g} /, / * \mathrm{~h} /, / * \mathrm{j} /, / * \mathrm{k} /, / * \mathrm{l} /, / * \mathrm{~m} /, / * \mathrm{n} /, / * \mathrm{p} /, / * \mathrm{r} /, / *_{\mathrm{s}} /, / *_{\mathrm{t}} /$,

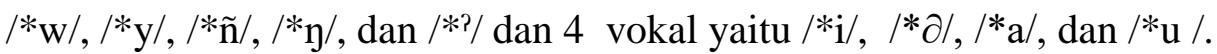

Sebagian besar fonem-fonem konsonan dan vokal PM masih dipertahankan keberadaannya oleh BMT. Dengan kata lain, masih ada kesamaan BMT dengan bahasa protonya, sedangkan konsonan-konsonan yang mengalami inovasi berjumlah 6 konsonan yaitu $* \mathrm{~h}<\varnothing /, *^{\mathrm{k}}</ \mathrm{r} /,{ }^{*} 1</ \mathrm{R} / *_{\mathrm{r}}</ \mathrm{R} /,{ }^{*} \mathrm{~s}</ \mathrm{h} /$ dan $* \mathrm{t}</$ / dan fonem vokal yang mengalami inovasi sebanyak 2 , yaitu: $*^{*} \mathrm{u}</ \mathrm{U} /$, dan $*_{\mathrm{a}}</ 00 /$

\section{DAFTAR PUSTAKA}

Adelaar, K. Alexander. (1992). Proto Malayic: The Reconstruction of Its Phonology and Parts of Its Lexicon and Morphology. Australian: Department of Linguistics Research School of Pacific Studies The Australian National University.

Akbar, M. Osra dkk. (1985) Pemetaan Bahasa Aceh, Gayo, dan Alas. Jakarta: Pusat Pembinaan dan Pengembangan Bahasa Departemen Pendidikan dan Kebudayaan. 1985

Durie, Mark. (1985) A Grammar of Acehnese on the Basis of a Dialect of North Aceh. USA: Foris Publication. Dordrecht-Holland/Cinnaminson-U.S.A.

Lumban Batu, Tri Julianti. (1998). Jenis-Jenis Kalimat Dalam Bahasa Melayu Tamiang di Kecamatan Karang Baru. Medan: Universitas Sumatra Utara Fakultas Sastra Jurusan Sasatra Daerah Program Studi Bahasa dan Sastra Melayu. 1998

Mahsun. (1995). Dialektologi Diakronis Sebuah Pengantar. Yogyakarta: Gadjah Mada Universiti Press.

\section{Cisarua, Bogor.}

Riswara, Yanti. (2011). Rekonstruksi Protofonem dan Inovasi Fonologis Bahasa Melayu Riau. Padang: Program Pasca Sarjana Universitas Andalas.

Sudaryanto. (1988). Metode Linguistik Bagian Kedua: Metode dan Aneka Teknik Mengumpulkan Data. Yogyakarta: Gadjah Mada University Press.

Tim Pemetaan Bahasa. (2008). Laporan Hubungan Kekerabatan dan Pemetaan BahasaBahasa di Provinsi Nanggore Aceh Darussalam. Banda Aceh: Departemen Pendidikan Nasional Balai Bahasa Banda Aceh.

Sugono, Dendy. (2008). Bahasa dan Peta Bahasa di Indonesia. Jakarta: Pusat Bahasa. http://melayuonline.com/ind/culture/dig/2693/nyeraya-etika-pergaulan-sosialmasyarakat-melayu-tamiang-nanggroe-aceh-darussalam. Diunduh tanggal 11 April 2012. 